\title{
胆管用 $\mathrm{T}$ チューブを使用した内視鏡下鼻内 $\mathrm{DCR}$ 法の検討
}

\author{
金沢医科大学耳鼻咽喉・頭頸科 \\ 村田英之，友田幸一
}

\section{はじめに}

涙囊鼻腔吻合術（以下 DCR）に使用するステント（以 下 N-S）は，通常 DCR 専用のヌンチャク型シリコンチ ユーブ（N-Sチューブ）を使用する。しかしながら眼 科側の意見も踏まえると, 内眼角の違和感や涙点の裂傷 など問題点も挙げられる。それらの点を考慮して，我々 はシリコンチューブに代えて胆管ドレナージ用のTチュ ーブ（以下 Tチューブ）をステントとして作成（図 1) し使用する試みを行ってきた。今回このステントを使用 した内視鏡下鼻内 DCR 法の内容と経過について報告し た。

\section{対 象}

対象は2001年 4 月〜2007年 3 月までに鼻涙管閉塞症と 診断され当院眼科から紹介となり，Tチューブを使用し 内視鏡下鼻内 DCR 法を行った症例のうち 1 年以上の経 過観察ができた20例 (23側)である。男女比はおよそ1：2 (男性 7 例 8 側, 女性13例15側), 年齢の平均は55.4歳 (34〜80歳), 過観察期間は 6 ケ月〜 5 年 4 ケ月（平均 3 年 6 ケ月）であった。

\section{手術手技}

術前に涙囊造影を行って，沪襄の大きさを確認してお く。手術は全例全身麻酔下に行った。まず鼻内から涙囊 位置を同定するために下涙小管から涙囊内にライトガイ ドを挿入する。内視鏡の光源を絞ると，下鼻甲介上方に 骨，粘膜を通して涙囊の位置が光輝する。その部位の粘 膜を切開する。骨を露出し，バーあるいはノミにて骨壁 を除去し涙囊外側壁を露出した。ライトガイドを露出し た涙囊壁に内側から押し出す様にテント状に緊張を加え る。角膜切開用メスにて涙囊壁に内腔まで横切開を加え ると多くの症例で白色の感染性涙液の排出を見る。涙囊 洗浄を行った後，Tチューブを挿入した。挿入後再び涙 囊洗浄を行って，Tチューブから抵抗なく洗浄液の排出 を確認した。骨露出部位をサージセルで覆い, タンポン を挿入して手術を終了した。

\section{術後処置と経過観察}

入院期間は 3 日〜 7 日で, 術後は眼科と共同で経過を 観察した。眼科では涙囊洗浄により通水の確認を，当科 では Tチューブ周囲の肉芽の増生や内腔の状態を必ず内 視鏡にて観察した。症状の悪化や通水で少しでも抵抗が あれば，当科で鼻内から Tチューブの状態を観察するよ うにした。また逆行性の感染の防止のため鼻を強くかま ないように患者に指導し，肉芽発生防止のためにステロ イドの点鼻を約 1 ケ月続けた。 $\mathrm{T}$ チューブは術後 6 ケ月 を目安に抜去するが，閉塞などのトラブルがなく症状も ない症例については抜去せずに経過を見ることにした (図 2)。

\section{術 後成 績}

全23側中，閉塞などのトラブルを認めた症例は 4 側 (13\%) で，全例が術後 3 ケ月以内に起きた。具体的に は, アレルギー合併例（粘膜の高度浮腫）, 鼻中隔彎曲 症例（処置が行い難く，Tチューブが涙囊内に落下）, Tチューブ位置の不具合例（先端が中鼻甲介に接触し閉 塞), 涙囊内に肉芽が発生例（ $\mathrm{T}$ チューブ内に肉芽が進 入)，であった。内 3 例は直ちにTチューブを抜去し， 再手術による挿入を行った。その内の 2 例は留置中， 1 例は抜去した。他 1 例は訴えがなかったため，閉塞した まま留置した状態である。

一方トラブルのない症例は19側（87\%）で，Tチュー ブの留置期間は，半年以内が10側，半年から一年が 5 側，一年が 5 側，一年以上が 3 側であった。Tチューブ 抜去後半年の時点の通水検查と自覚症状を検討すると, 通水が良好な症例が16側，不良の例が 3 例であった。ま た，自覚症状では改善があった症例が13側，なかったが 例が 6 側で，通水検査の結果との間に若干の差を認め た。通水が良好でも自覚症状の改善にそしい例は，全例 が75歳以上の高齢者であった。

\section{手術手技の検討}

我々の行っている手術手技について幾つかの点で考察 してみた。 


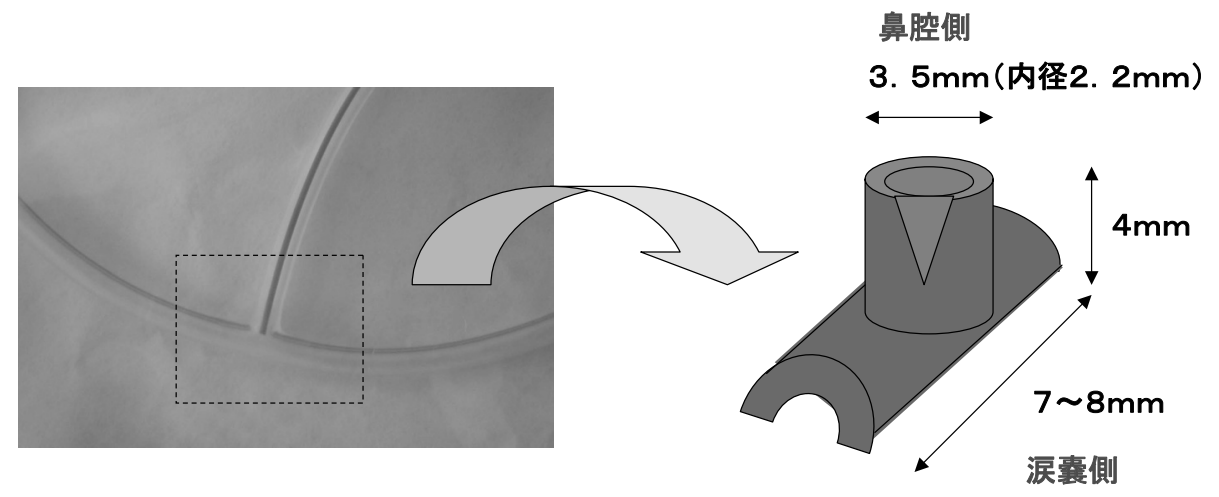

図 1

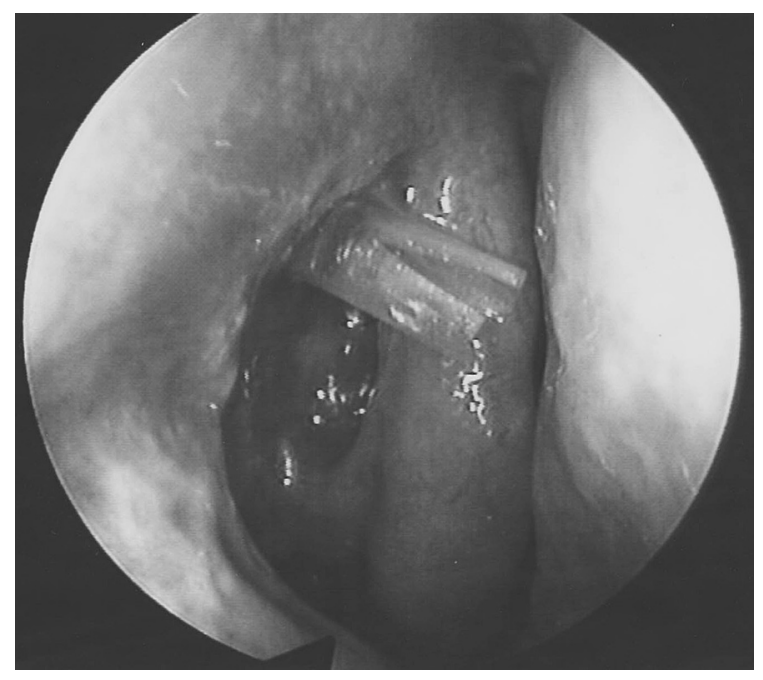

図 2

1. 涙囊と鼻腔の位置関係（中鼻道の状態と処理につい $\tau)$

Tチューブは中鼻道を横切るように挿入されるため に，鉤状突起の状態が扦入の際に問題となる。鈎状突起 の発達が良く, はり出しが強く中鼻道にスペースがない 症例は 17 側で，これらには銁状突起を除去すると共に前 篩骨洞を上方のみ開放しスペースを確保した。また， $\mathrm{T}$ チューブの先端が中鼻甲介に接触して術後に閉塞を起こ した例も見られた。これに対して鉤状突起のはり出しが 少なく，中鼻道にスペースのある症例は 5 側で，これら には鉤状突起と前篩骨洞の処理の必要はなかった。

2. 涙囊露出時の骨壁削開の部位と方法（削開のための 器械, 支援機器について)

涙囊位置の確認にライトガイドを使用した例が21側， 他の 2 側にはナビゲーションシステムを使用した。涙囊 が小さい例でもライトガイドを使用することによって涙 囊の位置を正確に鼻内より同定することができた。ナビ ゲーションシステムについては，涙囊の CT での同定率
が低いために有用ではなかった。骨壁の削開について は，ノミと骨鋭匙を用いた例が19側，バーを用いた例， レーザーを用いた例がそれぞれ 1 例であった。涙囊の鼻 腔側の骨壁は 2〜 3mm と厚い例もあり，ノミを使用し た方が一塊として骨壁を除去することができた。レーザ 一は骨に親和性が高いHo-YAGレーザーを使用した が，涙囊壁に孔が開いたり壁そのものが炭化し同定が困 難であった。最近は，マイクロデブリッダーを使用して いる ( 2 例)。

3. 涙囊壁切開の方法 (切開方法, 方向と器具について) 涙囊壁は視野のやや外側に位置するために，当初涙囊 壁の切開には鼻内手術用の対孔メスを使用した 4 側は, 先端に角度がなくスムースに切開することができなかっ た。このため角膜切開用メスを 60 度に弯曲させたものを 19側に使用した。涙囊内壁自体も慢性炎症のため肥厚し ており，角膜用メスの使用で内腔までしっかりと開放す ることが可能であった。切開方向について，縦切開を加 えた例が 4 側，横切開を加えた例が19側であった。特に Tチューブを挿入するためには横切開が適当であった。

4. ステントの挿入（ステントの種類と挿入方法につい て)

DCR に使用するステントは N-S チューブが一般的で あった。しかし術後の違和感が予想以上に強く，流涙な どの症状は抜去まで残る例が多かった。また涙小点間の 粘膜が裂傷を起こすことも多い。これに対してTチュー ブの挿入は多少難しいが術後の違和感も少なく，術翌日 から通水も良好であり流涙の症状も消失するため，今回 は全例に胆管用 Tチューブから作成したステントを使用 した。

\section{考察}

鼻内 DCR 法（N-S チューブを使用）については耳鼻 咽喉科の石尾ら ${ }^{1)}$ が術式の工夫の検討を行っており，耳 
鼻咽喉科医が果たす役割の大きさについても言及してい る。また，ステントについて栗橋ら ${ }^{2)}$ は N-S チューブ の有用性を涙道の詳細な解剖と共に述べている。我々の 症例全体で $80 \%$ 台という成績は決して高いものではない が，Tチューブ自体の違和感が全くないこと，術翌日か ら通水が可能な症例については自覚症状も消失している

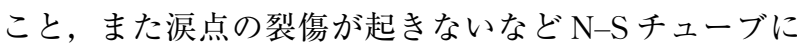
比較しての利点も多いことがわかった。しかしながらま だTチューブに一定の規格のある既製品がなく, 症例に よって大きさが一定しないこと, 挿入操作に慣れが必要 であることなど解決すべき問題も多い。また手術手技に ついても鼻内法か鼻外法か，あるいは N-S チューブか Tチューブかの選択，留置期間などの決定は施設ごとに 事情も異なり，議論もある。しかし鼻内内視鏡は耳鼻咽 喉科医の専門分野であるので，今後は眼科医と耳鼻咽喉 科が密接な連係を取っていく治療に当たる必要があると 考えられた。

\section{まと め}

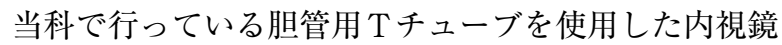
下鼻内 DCR 法について，その手術内容と成績につき報 告した。鼻涙管閉塞症の潜在患者は予想以上に多いと推
定され，今後はより低侵襲の鼻内 DCR 法が選択される と我々は考えている。鼻用内視鏡の使用は耳鼻咽喉科の 専門分野であり，今後はすべてを眼科に任せるのではな くより連係を深め手術にあたる必要があると考えた。

本稿を終えるにあたり，手術を通しご協力頂きました 金沢医科大学眼科学教室, 中泉裕子先生, 芹原清志先生 に深謝致します。

\section{参考文献}

1）石尾健一郎：内視鏡下鼻内涙囊鼻腔吻合術. 医学の あゆみ $1998 ； 187(3) ： 167-70$.

2 ) 栗橋克昭：涙道手術における内視鏡の重要性. 頭䅡 部外科 $1998 ； 8$ (1)：55-68.

別刷請求先：村田 英之

т $920-0265$

石川県河北郡内灘町大学 $1-1$

金沢医科大学耳鼻咽喉科

TEL：076-286-2211 FAX : 076-286-5566

E-mail : jibimura@kanazawa-med.ac.jp 